\title{
Pengaruh Kepemimpinan Visioner Kepala Madrasah terhadap Kedisiplinan Guru di MAN 2 Samarinda
}

\author{
Marantika1*, Dwi Nur Aini Dahlan² \\ 1IAIN Samarinda, Kota Samarinda, marantika2019@gmail.com \\ 2IAIN Samarinda, dwinur.ainidahlan19@gmail.com
}

\begin{abstract}
ABSTRAK
Kepemimpinan visioner adalah mampu melakukan perubahan dengan mempunyai visi dan ide-ide baru, berpikir kedepan, menjalankan tahapan saling menyambung yang dapat mempengaruhi dan memotivasi para guru dan siswanya. Penelitian ini dilakukan bertujuan untuk mengetahui pengaruh kepemimpinan Visioner Kepala Madrasah terhadap Kedisiplinan Guru. Jenis penelitian ini adalah penelitian kuantitatif. Populasi dalam penelitian ini ialah seluruh guru berjumlah 60 orang di Madrasah Aliyah Negeri 2 Samarinda. Teknik pengumpulan data menggunakan koesioner/angket, observasi dan dokumentasi. Adapun teknik analisis data menggunakan rumus korelasi product moment, koefisien determinan $\left(R^{2}\right)$ dan uji t. Hasil penelitian ini menunjukkan analisis data hasil nilai thitung 3,5090> tabel 2,00172, yang berarti Ho ditolak dan Ha diterima. Terdapat kolerasi antara variabel $\mathrm{X}$ dengan variabel $\mathrm{Y}$, korelasi product diperoleh angka sebesar 0,416 sehingga antara variabel kepemimpinan visioner dan variabel kedisiplinan guru terdapat kolerasi yang cukup kuat. Kepemimpinan visioner terhadap kedisiplinan guru hanya sebesar 17,30\% (cukup kuat), faktorfaktor yang menyebabkan hasil tersebut antara lain: memberikan kinerja terbaik tanpa menganalisa perubahan zaman, ketidakmampuan mengubah pengetahuan bawahan menjadi strategi, dan memperlakukan guru secara berbeda-beda sehingga mendapat pertentangan tugas. Sedangkan faktor pendukung dan penghambat dalam membina disiplin guru antara lain: kepribadian seorang guru, kepala madrasah dalam program dan pengawasan terhadap para guru.
\end{abstract}

Kata Kunci: Kepemimpinan, Visioner, Kepala Sekolah, Guru

\section{ABSTRACT}

Visionary leadership is a capability to make changes by having new visions and ideas, thinking ahead, carrying out stages of mutual interconnection that can influence and motivate teachers and their students. This research aims to find out the effect of leadership of Madrasah Principal Visionary to Teacher Discipline. The type of this research is quantitative research. The population in this study were all 60 teachers in MAN 2 Samarinda. The data of this research is obtained from questionnaire, observation and documentation. The data analysis technique uses product moment correlation formula, determinant coefficient $\left(R^{2}\right)$ and t test. The results of this study shows the results of the $t$-test value of 3.5090>t table 2.00172, which means that Ho is rejected and Ha is accepted. The meaning is there is a correlation between variable $\mathrm{X}$ and $\mathrm{Y}$, product correlation 0.416 . That means there is a strong correlation between visionary leadership variable and teacher discipline variable. Percentage of visionary leadership for teacher 
discipline is $17.30 \%$ (strong enough), the factors that cause these results include: giving the best performance without analyzing / following new era, inability to change teachers knowledge into strategy, and treating teachers differently causing conflicting duties. The supporting and inhibiting factors in managing teacher discipline include: teacher personalitty, the headmaster teachers supervision.

Keywords: Leadership, Visionary, Headmaster, Teacher

Article history:

Received : 7-10-2019

Revised : $27-12020$

Accepted : 10-2-2020

Copyright (c) 2020 Marantika, Dahlan

\section{Pendahuluan}

Kualitas

Pendidikan

merupakan salah satu cita-cita besar yang ingin dicapai oleh seluruh pihak bangsa Indonesia, sesuai amanat yang tertuang dalam alinea ke-4 (empat) UUD 1945 ialah untuk mencerdaskan kehidupan bangsa. Cita-cita bangsa tersebut kemudian dijabarkan melalui program-program pendidikan yang harapannya dapat menjadikan sistem pendidikan Indonesia menjadi lebih baik dan bermutu. Mengendalikan segala tindakan untuk selalu bergerak maju mengikuti perkembangan masyarakat dan kebudayaan bangsa (Ihsan, 2997:3).

Pendidikan ialah usaha sadar dan terencana untuk mewujudkan suasana belajar dan proses pembelajaran agar peserta didik secara aktif mengembangkan potensi dirinya untuk memiliki kekuatan spiritual, keagamaan, pengendalian diri, kepribadian, kecerdasan, akhlak mulia, serta keterampilan yang diperlukan dirinya, masayarakat, bangsa, dan negara. Pengelolaan pendidikan tidak hanya dibebankan kepada satu pihak saja, melainkan sebuah konsep atau sistem yang saling terhubung antara satu dengan yang lainnya (Suryana \& Suryadi, 2012: 6).

Kualitas pendidikan yang baik merupakan salah satu modal dasar yang penting bagi terlaksananya proses pembentukan generasi masa depan lebih baik. Pembentukan generasi yang baik tidak lepas dari sosok seorang pemimpin yang mempunyai peran penting dalam meningkatkan kinerja maupun perilaku pegawai. Pencapaian keberhasilan sebuah organisasi pendidikan juga tak lepas dari peran penting seorang pemimpin. 
Organisasi pendidikan mengharapkan adanya pemimpin yang kuat untuk pencapaian efektivitas yang optimal, pada masa ini dimana dunia memiliki dinamika yang fluktuatif, dibutuhkan pemimpin yang mampumenciptakan visi yang jauh ke depan, mampu menginspirasi para anggota organisasinya untuk mau mencapai visi tersebut. Organisasi madrasah yang dipimpin oleh seorang pemimpin yaitu kepala madrasah yang memiliki tugas dan wewenang dalam menciptakan visi dan misi serta mengatur segala aktivitas di dalam madrasah yang dikelolanya. Sewajarnya seorang pemimpin membekali dirinya dengan kemampuan yang baik.

Seorang kepala madrasah menjadi nahkoda bagi sekolah untuk menjadikan institusi yang dipimpinnya menjadi teladan. Kepala madrasah merupakan subjek yang paling diharapkan banyak orang, khususnya para bawahan dan masyarakat, agar mampu mendorong dan mengantarkan kemajuan lembaga pendidikan. Setiap terjadi pergantian kepemimpinan dalam suatu lembaga pendidikan, selalu muncul harapan-harapan besar untuk membawa kemajuan lembaga pendidikan yang dipimpinnya.

Kepala madrasah sebagai figur sentral harus menyadari bahwa terbentuknya kebiasaan, sikap, dan perilaku dalam konteks disiplin sekolah sangat dipengaruhi oleh pribadi, gaya kepemimpinan, dan cara dia melihat perkembangan ke depan yang bersifat visioner. Perkembangan disiplin sekolah yang lebih baik dan sehat harus dimulai dari kepemimpinan kepala madrasah. Kepala madrasah yang mampu membangun tim kerja, belajar dari guru, staf tata usaha dan siswa, terbuka untuk jalur komunikasi dengan lingkungan, luas akses informasi akan mampu mengembangkan kultur positif sekolah (Kompri, 2016: 128).

Kepala madrasah harus dapat menjaga dan memelihara keseimbangan kepentingan antara guru, staf dengan siswa, kepentingan pribadi kepala madrasah maupun kepentingan masyarakat. Kemampuan dalam menciptakan suasana keseimbangan, keserasian antara kehidupan sekolah dengan lingkungan eksternal. Memberikan bimbingan, mengadakan koordinasi kegiatan, mengadakan pengendalian 
atau pengawasan, mengadakan pembinaan agar masing-masing anggota atau bawahan memperoleh tugas yang wajar dalam beban dan hasil usaha bersama untuk mencapai visi yang ditargetkan.

Kepala Madrasah memiliki beragam tugas dan tanggung jawab terhadap proses pembelajaran maupun aktivitas pengembangan diri dapat berjalan dengan baik dan dapat meningkatkan kedisiplinan seluruh masyarakat madrasah. Salah satu budaya yang harus diperhatikan dan dikembangkan adalah kedisiplinan. Kedisiplinan merupakan salah satu syarat mutlak menggapai kesuksesan dalam menggapai cita-cita besar dalam dunia pendidikan (Mutaqin, 2010: 87).

Perubahan dan kemajuan lembaga sekolah dalam meningkatkan kegiatan-kegiatan di madrasah harus adanya pemimpin visioner yang mempunyai visi dan ideide baru, berpikir ke depan, menjalankan tahapan saling menyambung tidak ada satu tahapan pun yang terputus. Menjalankan pembiasaan disiplin dan menghargai waktu dimulai dari kepala sekolah itu sendiri, kemudian dapat mempengaruhi dan memotivasi para guru serta siswanya. Semakin baik disiplin seseorang maka semakin tinggi prestasi kerja yang dapat dicapainya.

Kedisiplinan bagi guru sedikit banyak akan mempengaruhi hasil mengajarnya dan kedisiplinan ini harus dimulai dari guru sebagai teladan yang utama dan akan tertular kepada siswa-siswanya. Salah satu sekolah yang amat memperhatikan dan mengembangkan akan pentingnya kedisiplinan ialah Madrasah Aliyah Negeri 2 Samarinda bahwasanya fakta yang dapat dilihat dari segi adanya fingerprint hadir dan pulang, jadwal pakaian yang ditentukan, serta membuat surat keterangan jika tidak hadir di sekolah, dan guru wajib turut hadir dalam kegiatan muhadhoroh siswa setiap harinya sesudah sholat dzuhur. Sebuah keberhasilan yang dicapai dalam lembaga apapun itu berawal dari kedisiplinan.

Madrasah Aliyah Negeri 2 Samarinda merupakan salah satu madrasah negeri unggul yang ada di kota Samarinda. Posisinya yang strategis dekat dengan pusat kota membuat madrasah ini memiliki daya tarik tersendiri bagi calon siswa yang ingin melanjutkan pendidikan ke 
jenjang sekolah menengah tingkat atas. Madrasah tersebut memiliki keunggulan dibidang pemahaman Agama Islam sesuai dengan mottonya yang Islami, Populis dan Berkualitas yang menjadi acuan bagi lembagalembaga pendidikan sejenis, dengan predikatnya sebagai madrasah percontohan (model).

Aspek yang menjadi bagian kedisiplinan guru di MAN 2 Samarinda meliputi ketepatan waktu, frekuensi kehadiran, cara berpakaian, ketepatan waktu rapat di sekolah, pemanfaatan media, ketaatan pada prosedur kerja, ketaatan terhadap instruksi atasan, serta tanggung jawab terhadap pekerjaan yang diberikan. Kelebihan yang dimiliki oleh MAN 2 Samarinda ialah visi misi yang dijalankan dengan baik, sarana dan prasarana yang memadai, program tambahan MAN-PK (Program Keagamaan). Mengenai kurikulum yang dijalankan, MAN 2 Samarinda tetap konsisten menjalankan kurikulum 13 yang terintegrasi, serta mengedepankan prestasi dan kreativitas yang diraih oleh siswasiswinya tersebut dalam hal akademik maupun non akademik.

Madrasah Aliyah Negeri 2 Samarinda dalam kurun lima tahun terakhir telah menunjukkan eksistensinya sebagai salah satu madrasah terkemuka dan berprestasi baik ditingkat lokal, regional maupun nasional. Madrasah tersebut juga pada tahun terakhir ini mengalami peningkatan setiap minggunya para siswa-siswi banyak meraih juara perlombaan. Madrasah tersebut pula ditetapkan menjadi peserta lomba Adiwiyata tingkat nasional tahun 2019. Berdasarkan uraian di atas, maka perlu dilakukan penelitian yang spesifik berkaitan dengan "Pengaruh Kepemimpinan Visioner Kepala Madrasah Aliyah Negeri 2 Samarinda terhadap Tingkat Kedisiplinan Guru". Penelitian ini bertujuan untuk mengetahui pengaruh Kepemimpinan Visioner Kepala Madrasah terhadap Kedisiplinan Guru.

\section{METODE PENELITIAN}

Jenis penelitian ini adalah penelitian kuantitatif yaitu penelitian yang mengandalkan pembenaran dan pembuktian teori dalam bentuk fakta empiris, cenderung bersifat pasti, disesuaikan dengan fakta di lapangan atau berdasarkan dari hukum logika matematika yang dipakai (Muliawan, 2014:60). Populasi dalam penelitan ini adalah seluruh guru MAN 2 
Samarinda berjumlah 60 orang. Suharsimi Arikunto mengemukakan bahwa "apabila objeknya kurang dari 100, lebih baik diambil semua sehingga penelitiannya merupakan penelitian populasi. Teknik pengumpulan data dalam penelitian ini adalah menggunakan angket, observasi dan dokumentasi (Arikunto, 2016: 112).

Angket digunakan untuk memperoleh data yang diperlukan dalam menjawab permasalahan. Teknik pengumpulan data dengan metode kuisioner/angket tentang kepemimpinan dan kedisiplinan diajukan kepada seluruh guru. Observasi dilakukan untuk melihat bagaimana proses kepemimpinan visioner kepala madrasah di lokasi penelitian tersebut. Teknik pengumpulan data dengan teknik ini juga untuk melihat bagaimana kinerja guru yang ada di lokasi penelitian tersebut. Dokumentasi dilakukan untuk mengumpulkan data-data dari MAN 2 Samarinda yang berkaitan dan berguna bagi penelitian.

Hipotesis dalam penelitian ini ialah ada pengaruh kepemimpinan visioner kepala madrasah terhadap kedisiplinan guru sebesar 3,5090 yang berarti antara pengaruh kepemimpinan visioner terhadap kedisiplinan guru di MAN 2 Samarinda adalah Ho ditolak dan $\mathrm{Ha}$ diterima. Sehingga, mengisyaratkan adanya korelasi antara variabel $\mathrm{X}$ dengan variabel $\mathrm{Y}$ atau terdapat pengaruh kepemimpinan visioner kepala madrasah terhadap kedisiplinan guru.

Indikator dalam penelitian ini terbagi menjadi dua bagian yaitu indikator kepemimpinan visioner kepala madrasah dan indikator kedisiplinan guru. Pengumpulan data pada instrument penelitian ini berupa angket.

Indikator yang terdapat dalam kepemimpinan visioner kepala madrasah yaitu: Penentu arah, Agen perubahan, juru bicara, dan mentor. Sedangkan indikator dalam kedisplinan guru yaitu: adanya tata tertib dan ketentuan-ketentuan, adanya kebutuhan para pengikut, ketaatan terhadap instruksi atasan, disiplin dalam berpakaian, dan disiplin waktu dalam mengajar.

Data yang diperoleh kemudian diolah dan dianalisis kedalam presentase frekuensi masing-masing variable. 
Tabel 1

Kisi-Kisi Instrumen Kepemimpinan Visioner

Kepala Madrasah

\begin{tabular}{|c|c|c|c|c|}
\hline Variabel & Aspek & Indikator & & \\
\hline & & & Positif & Negatif \\
\hline Kepemimpinan & Penentu Arah & Berwawasan ke depan & $1,2,4$ & 3,5 \\
\hline Visioner Kepala & & Memberikan Kinerja Terbaik & 6,8 & 7,9 \\
\hline Madrasah & & $\begin{array}{l}\text { Menggerakkan dan mendorong } \\
\text { bawahan }\end{array}$ & 10,12 & 11,13 \\
\hline & Agen Perubahan & Percaya diri dan teliti & 14,16 & 12,17 \\
\hline & & menghadapi Berbagai tantangan & & \\
\hline & & $\begin{array}{l}\text { Merumuskan visi yang Jelas, } \\
\text { inspirasional dan menggugah }\end{array}$ & $22,25,45$ & 23,24 \\
\hline & & Mewujudkan rencana Menjadi & 18,19 & 20,21 \\
\hline & & kenyataan & & \\
\hline & Juru Bicara & Memberikan inspirasi, bekerja & $26,27,30$ & 28,29 \\
\hline & & keras, kerjasama dan kreatif & & \\
\hline & & Menjadi teladan & $31,33,34$ & 32,35 \\
\hline & & Memberikan penghargaan dan & 36,39 & 37,38 \\
\hline & & respect kepada Bawahan & & \\
\hline & & Memiliki hubungan yang Baik & $40,42,43$ & 41,44 \\
\hline & & dengan masyarakat Sekolah dan & & \\
\hline & & diluar & & \\
\hline & Mentor & Inovatif dan proaktif & $46,47,50$ & 48,49 \\
\hline & & Merubah Paradigma Pemikiran & 51,54 & 52,53 \\
\hline & & konvensional ke paradigma baru & & \\
\hline & & Berfikir kreatif dan produktif & $55,56,59$ & 57,58 \\
\hline & & Menerima Aspiratif & 60,63 & 61,62 \\
\hline & & Tanggung Jawab yang Tinggi & 64,67 & 65,66 \\
\hline
\end{tabular}

Jumlah

Tabel 2

Kisi-Kisi Instrumen Tingkat Kedisiplinan Guru

\begin{tabular}{|c|c|c|c|c|}
\hline \multirow[t]{2}{*}{ Variabel } & \multirow[t]{2}{*}{ Aspek } & \multirow[t]{2}{*}{ Indikator } & \multicolumn{2}{|c|}{ Item } \\
\hline & & & Positif & Negatif \\
\hline \multirow[t]{4}{*}{$\begin{array}{l}\text { Kedisiplinan } \\
\text { Guru }\end{array}$} & \multirow{4}{*}{$\begin{array}{c}\text { Adanya tata tertib } \\
\text { dan ketentuan- } \\
\text { ketentuan }\end{array}$} & $\begin{array}{l}\text { Guru menaati tata tertib yang } \\
\text { berlaku di sekolah }\end{array}$ & 1,4 & 2,3 \\
\hline & & $\begin{array}{l}\text { Bertanggung Jawab Terhadap } \\
\text { Pekerjaan }\end{array}$ & 5,8 & 6,7 \\
\hline & & $\begin{array}{l}\text { Ketepatan waktu rapat di } \\
\text { sekolah }\end{array}$ & 9,12 & 10,11 \\
\hline & & Pemberian Sanksi dan Reward & 13,16 & 14,15 \\
\hline
\end{tabular}




\begin{tabular}{|c|c|c|c|c|}
\hline \multirow[t]{2}{*}{ Variabel } & Aspek & Indikator & \multicolumn{2}{|c|}{ Item } \\
\hline & & & Positif & Negatif \\
\hline & \multirow[t]{3}{*}{$\begin{array}{l}\text { Adanya Kebutuhan } \\
\text { para pengikut }\end{array}$} & $\begin{array}{l}\text { Memegang teguh kepercayaan } \\
\text { yang diberikan }\end{array}$ & 17,20 & 18,19 \\
\hline & & $\begin{array}{l}\text { Ketaatan dan kepatuhan } \\
\text { terhadap peraturan yang } \\
\text { berlaku }\end{array}$ & 21,24 & 22,23 \\
\hline & & $\begin{array}{l}\text { Bekerja dengan inovatif, kreatif, } \\
\text { cermat, dan semangat }\end{array}$ & $25,27,28$ & 26,29 \\
\hline & \multirow[t]{4}{*}{$\begin{array}{l}\text { Ketaatan terhadap } \\
\text { instruksi atasan }\end{array}$} & $\begin{array}{l}\text { Bekerja dengan Mengikuti cara } \\
\text { yang telah ditentukan }\end{array}$ & 30,31 & 32,33 \\
\hline & & $\begin{array}{l}\text { Mengikuti Seminar, Workshop, } \\
\text { dan Pelantikan }\end{array}$ & 34,35 & 36,37 \\
\hline & & Mengikuti HAB Kemenag & 38,39 & 40,41 \\
\hline & & $\begin{array}{l}\text { Mengikuti upacara Hari PGRI } \\
\text { setiap Tahunnya }\end{array}$ & 42,45 & 43,44 \\
\hline & $\begin{array}{l}\text { Displin dalam } \\
\text { Berpakaian }\end{array}$ & $\begin{array}{l}\text { Menggunakan seragam sesuai } \\
\text { dengan peraturan yang ada }\end{array}$ & 46,49 & 47,48 \\
\hline & Disiplin Kehadiran & $\begin{array}{l}\text { Guru hadir di sekolah dan } \\
\text { pulang pada waktu yang } \\
\text { ditentukan }\end{array}$ & $50,51,54$ & 52,53 \\
\hline & \multirow[t]{4}{*}{$\begin{array}{l}\text { Disiplin waktu dalam } \\
\text { Mengajar }\end{array}$} & $\begin{array}{l}\text { Memasuki kelas sebelum jam } \\
\text { Pelajaran dimulai }\end{array}$ & $55,58,59$ & 56,57 \\
\hline & & $\begin{array}{l}\text { Keluar kelas setelah jam } \\
\text { pelajaran berakhir }\end{array}$ & 60,61 & 62,63 \\
\hline & & $\begin{array}{l}\text { Persiapan-persiapan dalam } \\
\text { mengajar }\end{array}$ & $64,67,68$ & 65,66 \\
\hline & & $\begin{array}{l}\text { Apabila guru tidak bisa hadir } \\
\text { guru tetap memberikan tugas } \\
\text { kepada siswa }\end{array}$ & 69,70 & 71,72 \\
\hline
\end{tabular}

\section{Jumlah}

Keabsahan data menggunakan uji validitas menggunakan perhitungan aplikasi IBM SPSS statistik versi 21 dan uji realibilitas digunakan rumus Alpha Cronbach karena instrumen penelitian ini berbentuk angket dan skala bertingkat. Dimana kuesioner dikatakan reliabel nilai Cronbach alpha lebih besar dari 0,70 (Sarmanu, 2017: 9).

Sedangkan teknik analisis data menggunakan Product Moment, merupakan teknik untuk mencari kolerasi antara dua variabel yang dikembangkan oleh person dan biasa disebut juga dengan teknik kolerasi person. Kemudian untuk menentukan besarnya 
sumbangan (koefisien diterminan atau koefisien penentu) variabel $\mathrm{X}$ (Kepemimpinan Visioner Kepala Madrasah) terhadap variabel $\mathrm{Y}$ (Tingkat Kedisiplinan Guru), selanjutnya untuk menguji data yang ada, serta menentukan hipotesis diterima atau ditolak, maka dipergunakan rumus uji t.

\section{HASIL DAN PEMBAHASAN}

Adapun hasil perhitungan mengenai uji validitas angket secara rinci ada pada lampiran, sedangkan secara ringkas dapat dilihat pada Tabel VI sebagai berikut:

Tabel 3

Hasil Uji Validitas Angket

\begin{tabular}{clccc}
\hline No & Variabel & $\begin{array}{c}\text { Jumlah } \\
\text { Butir }\end{array}$ & Valid & $\begin{array}{c}\text { Tidak } \\
\text { Valid }\end{array}$ \\
\hline $\mathbf{1}$ & $\begin{array}{l}\text { Kepemimpin } \\
\text { an Visioner }\end{array}$ & 67 & 43 & 24 \\
& $\begin{array}{l}\text { Kepala } \\
\text { Madrasah }\end{array}$ & & & \\
\hline $\mathbf{2}$ & $\begin{array}{l}\text { Kedisiplinan } \\
\text { Guru }\end{array}$ & 72 & 36 & 36 \\
& & & \\
\hline
\end{tabular}

Pada penelitian ini sudah dilakukan uji coba instrumen, berdasarkan uji validitas dan reliabilitas instrumen terdapat 43 butir soal yang valid dan terdapat 24 soal dinyatakan tidak valid pada variabel kepemimpinan visioner kepala madrasah. Sedangkan pada variabel kedisiplinana guru terdapat 146
36 butir soal yang valid dan 36 butir soal dinyatakan tidak valid.

Hasil koefisien realibilitas instrument gaya kepemimpinan visioner kepala madrasah adalah sebesar $=0,823$. Dan hasil koefisien realibilitas instrumen kedisiplinan guru adalah sebesar 0,755 sedangkan nilai $r_{\text {tabel }}$ adalah 0,600 , berarti kedua data tersebut reliabel atau memenuhi persyaratan. Untuk lebih jelasnya dapat dilihat pada tabel VII berikut:

Tabel 4

Hasil Uji Reliabilitas

\begin{tabular}{clccc}
\hline No. & Variabel & r hitung & r table & $\begin{array}{c}\text { Kesimp } \\
\text { ulan }\end{array}$ \\
\hline $\mathbf{1}$ & $\begin{array}{l}\text { Kepemim } \\
\text { pinan }\end{array}$ & 0,823 & 0,60 & Reliabel \\
& Visioner & & 0 & \\
& Kepala & & & \\
& Madrasah & & & \\
\hline $\mathbf{2}$ & Kedisiplin & 0,755 & 0,60 & Reliabel \\
& an Guru & & 0 & \\
\hline
\end{tabular}

\section{A. Hasil Angket Kepemimpinan Visioner}

Berdasarkan indikator-indikator yang penulis tuangkan dalam bentuk pernyataan-pernyataan di dalam angket yang disampaikan kepada 60 responden, adapun angket yang dibagikan ke responden adalah angket yang telah divalidasi. Angket tersebut terdiri dari 43 pernyataan yang dengan jenis pernyataan negatif 
dan penyataan positif diperoleh. madrasah dapat dilihat pada tabel IX Untuk lebih jelasnya data tentang berikut:

kepemimpinan visioner kepala

Tabel 5

Hasil Angket Kepemimpinan Visioner

Kepala Madrasah

\begin{tabular}{|c|c|c|c|c|c|}
\hline \multirow[t]{3}{*}{ Nomor Item } & \multicolumn{5}{|c|}{ Hasil Jawaban } \\
\hline & Selalu & Sering & Kadang- & Tidak & Jumlah \\
\hline & & & kadang & Pernah & Guru \\
\hline 1 & 18 & 22 & 20 & 0 & 60 \\
\hline 2 & 12 & 14 & 33 & 1 & 60 \\
\hline 3 & 14 & 37 & 9 & 0 & 60 \\
\hline 4 & 16 & 27 & 5 & 12 & 60 \\
\hline 5 & 7 & 10 & 39 & 4 & 60 \\
\hline 6 & 29 & 31 & 0 & 0 & 60 \\
\hline 7 & 33 & 23 & 4 & 0 & 60 \\
\hline 8 & 12 & 17 & 28 & 3 & 60 \\
\hline 9 & 17 & 43 & 0 & 0 & 60 \\
\hline 10 & 8 & 4 & 8 & 40 & 60 \\
\hline 11 & 35 & 25 & 0 & 0 & 60 \\
\hline 12 & 10 & 13 & 24 & 13 & 60 \\
\hline 13 & 13 & 41 & 6 & 0 & 60 \\
\hline 14 & 16 & 43 & 1 & 0 & 60 \\
\hline 15 & 42 & 16 & 2 & 0 & 60 \\
\hline 16 & 12 & 11 & 16 & 21 & 60 \\
\hline 17 & 20 & 38 & 2 & 0 & 60 \\
\hline 18 & 30 & 30 & 0 & 0 & 60 \\
\hline 19 & 27 & 33 & 0 & 0 & 60 \\
\hline 20 & 24 & 24 & 12 & 0 & 60 \\
\hline 21 & 18 & 30 & 12 & 0 & 60 \\
\hline 22 & 4 & 1 & 37 & 18 & 60 \\
\hline 23 & 0 & 2 & 17 & 41 & 60 \\
\hline 24 & 17 & 35 & 8 & 0 & 60 \\
\hline 25 & 0 & 4 & 22 & 34 & 60 \\
\hline 26 & 17 & 34 & 9 & 0 & 60 \\
\hline 27 & 15 & 32 & 13 & 0 & 60 \\
\hline 28 & 13 & 46 & 1 & 0 & 60 \\
\hline 29 & 33 & 25 & 2 & 0 & 60 \\
\hline 30 & 15 & 37 & 8 & 0 & 60 \\
\hline 31 & 33 & 18 & 9 & 0 & 60 \\
\hline 32 & 22 & 26 & 12 & 0 & 60 \\
\hline 33 & 10 & 14 & 23 & 13 & 60 \\
\hline
\end{tabular}




\begin{tabular}{cccccc}
\hline Nomor Item & Selalu & Sering & $\begin{array}{c}\text { Hasil Jawaban } \\
\text { Kadang- } \\
\text { kadang }\end{array}$ & $\begin{array}{c}\text { Tidak } \\
\text { Pernah }\end{array}$ & $\begin{array}{c}\text { Jumlah } \\
\text { Guru }\end{array}$ \\
\hline $\mathbf{3 4}$ & 2 & 10 & 15 & 33 & 60 \\
\hline $\mathbf{3 5}$ & 20 & 32 & 8 & 0 & 60 \\
\hline $\mathbf{3 6}$ & 32 & 28 & 0 & 0 & 60 \\
\hline $\mathbf{3 7}$ & 25 & 3 & 7 & 25 & 60 \\
\hline $\mathbf{3 8}$ & 0 & 0 & 10 & 50 & 60 \\
\hline $\mathbf{3 9}$ & 40 & 20 & 0 & 0 & 60 \\
\hline $\mathbf{4 0}$ & 29 & 24 & 7 & 0 & 60 \\
\hline $\mathbf{4 2}$ & 0 & 6 & 43 & 11 & 60 \\
\hline $\mathbf{4 3}$ & 0 & 5 & 18 & 37 & 60 \\
\hline Jumlah & $\mathbf{7 4 0}$ & $\mathbf{9 5 7}$ & $\mathbf{5 0 6}$ & $\mathbf{3 7 7}$ & $\mathbf{2 5 8 0}$ \\
\hline
\end{tabular}

Untuk dapat mengetahui kepemimpinan visioner kepala madrasah di MAN 2 Samarinda, maka tiap frekuensi alternatif jawaban dikalikan dengan skor nilai masingmasing jawabanhasil yang diperoleh adalah: Alternatif jawaban dikalikan dengan skor nilai masing-masing. Hasil yang diperoleh adalah 70\%.

Dengan demikian, maka dapat disimpulkan Kepemimpinan visioner kepala madrasah di MAN 2 Samarinda yang dilihat dari 43 pernyataan dikatagorikan "Baik" dengan persentase $70 \%$.

\section{B. Hasil Angket Kedisiplinan Guru}

Berdasarkan

indikatorindikator yang penulis tuangkan dalam bentuk pernyataan-pernyataan di dalam angket yang disampaikan kepada 60 responden, adapun angket yang dibagikan ke responden adalah angket yang telah divalidasi. Angket tersebut terdiri dari 36 pernyataan yang dengan jenis pernyataan negatif dan penyataan positif diperoleh. Untuk lebih jelasnya data tentang kedisiplinan guru dapat dilihat pada tabel X berikut:

Tabel 6

Hasil Angket Kedisiplinan Guru

\begin{tabular}{cccccc}
\hline Nomor Item & Selalu & Sering & $\begin{array}{c}\text { Hasil Jawaban } \\
\text { Kadang- } \\
\text { kadang }\end{array}$ & Tidak Pernah & $\begin{array}{c}\text { Jumlah } \\
\text { Guru }\end{array}$ \\
\hline $\mathbf{1}$ & 21 & 15 & 24 & 0 & 60 \\
\hline $\mathbf{2}$ & 26 & 33 & 1 & 0 & 60 \\
\hline $\mathbf{3}$ & 0 & 11 & 21 & 28 & 60
\end{tabular}




\begin{tabular}{|c|c|c|c|c|c|}
\hline \multirow[t]{3}{*}{ Nomor Item } & \multicolumn{5}{|c|}{ Hasil Jawaban } \\
\hline & Selalu & Sering & Kadang- & Tidak Pernah & Jumlah \\
\hline & & & kadang & & Guru \\
\hline 4 & 5 & 11 & 7 & 37 & 60 \\
\hline 5 & 27 & 22 & 11 & 0 & 60 \\
\hline 6 & 5 & 8 & 24 & 23 & 60 \\
\hline 7 & 0 & 20 & 32 & 8 & 60 \\
\hline 8 & 0 & 1 & 33 & 26 & 60 \\
\hline 9 & 29 & 20 & 11 & 0 & 60 \\
\hline 10 & 0 & 0 & 12 & 48 & 60 \\
\hline 11 & 0 & 0 & 28 & 32 & 60 \\
\hline 12 & 12 & 29 & 19 & 0 & 60 \\
\hline 13 & 27 & 32 & 1 & 0 & 60 \\
\hline 14 & 27 & 33 & 0 & 0 & 60 \\
\hline 15 & 34 & 26 & 0 & 0 & 60 \\
\hline 16 & 0 & 1 & 23 & 36 & 60 \\
\hline 17 & 27 & 11 & 22 & 0 & 60 \\
\hline 18 & 7 & 53 & 0 & 0 & 60 \\
\hline 19 & 9 & 15 & 15 & 21 & 60 \\
\hline 20 & 17 & 33 & 10 & 0 & 60 \\
\hline 21 & 48 & 12 & 0 & 0 & 60 \\
\hline 22 & 0 & 0 & 1 & 59 & 60 \\
\hline 23 & 0 & 0 & 11 & 49 & 60 \\
\hline 24 & 29 & 30 & 1 & 0 & 60 \\
\hline 25 & 19 & 41 & 0 & 0 & 60 \\
\hline 26 & 47 & 13 & 0 & 0 & 60 \\
\hline 27 & 0 & 0 & 36 & 24 & 60 \\
\hline 28 & 1 & 13 & 45 & 1 & 60 \\
\hline 29 & 33 & 27 & 0 & 0 & 60 \\
\hline 30 & 28 & 26 & 6 & 0 & 60 \\
\hline 31 & 28 & 16 & 16 & 0 & 60 \\
\hline 32 & 2 & 4 & 54 & 0 & 60 \\
\hline 33 & 0 & 0 & 23 & 37 & 60 \\
\hline 34 & 0 & 10 & 33 & 17 & 60 \\
\hline 35 & 34 & 26 & 0 & 0 & 60 \\
\hline 36 & 38 & 22 & 0 & 0 & 60 \\
\hline Jumlah & 580 & 614 & 520 & 446 & 2580 \\
\hline
\end{tabular}

Untuk dapat mengetahui skor nilai masing-masing tingkat kedisiplinan guru di MAN 2 jawaban.hasil yang diperoleh adalah: Samarinda, maka tiap frekuensi Alternatif jawaban dikalikan dengan alternatif jawaban dikalikan dengan 
skor nilai masing-masing. Hasil yang diperoleh adalah $65 \%$.

Dengan demikian, maka dapat disimpulkan tingkat kedisiplinan guru di MAN 2 Samarinda yang dilihat dari 36 pernyataan dikatagorikan "Baik" dengan persentase 65\%.

\section{Hasil Analisis Data}

Hasil analisis diperoleh dengan perhitungan secara manual dan menggunakan IBMSPSS24 memperoleh hasil $\mathrm{r}_{\text {hitung }}$ sebesar 0,416. Hasil tersebut kemudian dikonsultasikan dengan $r_{\text {tabel }}$ sebesar $0,250(a=0,05$ dan $\mathrm{N}=60$ ). Hasil perhitungan tersebut menunjukan bahwa $\mathrm{r}$ hitung $\geq$ $r$ tabel, $0,416 \geq 0,250$. Hal ini menunjukan bahwa ada pengaruh kepemimpinan visioner kepala madrasah terhadap tingkat kedisiplinan guru di Madrasah Aliyah Negeri 2 Samarinda.

Dari perhitungan koefisien determinan diketahui bahwa kontribusi (sumbangan) kepemimpinan visioner kepala madrasah terhadap kedisiplinan guru adalah sebesar $17,31 \%$ sedangkan $82,69 \%$ ditentukan oleh faktor lain.

Setelah diperoleh nilai " $r$ " maka dilakukan pengujian signifikansi koefisien kolerasi, dengan menggunakan rumus uji " $\mathrm{t}$ " sebagai berikut: Apabila dilihat tabel $\mathrm{t}$ pada taraf kebenaran $5 \%$ dan tingkat derajat kebebasan $(\mathrm{db})=58$ diperoleh $\mathrm{t}_{\text {tabel }}=2,00172$ sedangkan $\mathrm{t}_{\text {hitung }}$ yang diperoleh sebesar 3,5090 karena $\mathrm{t}_{\text {hitung }}=3,5090>\mathrm{t}_{\text {tabel }}=2,00172$ yang berarti antara pengaruh kepemimpinan visioner terhadap tingkat kedisiplinan guru di MAN 2 Samarinda adalah Ho ditolak dan $\mathrm{Ha}$ diterima. Sehingga, mengisyaratkan adanya korelasi antara variabel $\mathrm{X}$ dengan variabel $\mathrm{Y}$ atau terdapat pengaruh kepemimpinan visioner kepala madrasah terhadap tingkat kedisiplinan guru.

Kemudian, dalam membina disiplin guru ada faktor pendukung dan penghambat baik yang bersifat internal maupun eksternal. Faktor pendukung dari internal yaitu berasal dari dari guru itu sendiri seperti kepribadian, karena kepribadian salah satu faktor yang sangat penting dalam mewujudkan kedisiplinan dalam kepribadian seorang guru akan tercermin bagaimana dia akan mengajarkan siswa-siswanya, sehingga kepribadian baik akan di jadikan sebagai panutan oleh anak murid dan bahkan guru-guru yang lainnya. Dan faktor pendukung dari eksternal yaitu berasal dari kepala 
madrasah, dimana kepala madrasah yang memiliki visioner yang baik dalam program dan pengawasan terhadap guru-guru yang ada dalam madrasah tersebut akan membuat disiplin kinerja guru menjadi tetap teratur tidak naik-turun sehingga hasil yang diinginkan dapat dicapai dengan maksimal.

Sedangkan faktor pendukung baik yang bersifat internal maupun eksternal kepala madrasah secara optimal memanfaatkan secara maksimal potensi tersebut. Kepada guru-guru yang disiplin diberikan reward walau hanya sekedar pujian. Kepala madrasah selaku pemimpin madrasah yang mempunyai peran sebagai penentu arah, agen perubahan, juru bicara, dan mentor maka kepala madrasah dalam membina disiplin guru berusaha melakukan perbuatan yang melahirkan kemauan untuk bekerja dengan penuh semangat dan percaya diri pada bawahannya. Kepala madrasah berani bertindak tegas untuk menegakkan disiplin guru. Kepala madrasah berani memberikan sanksi atau teguran bagi guru yang melanggar disiplin melalui pendekatan persuasif karena kedisiplinan guru memegang peranan yang sangat strategis dalam mendukung hasil pendidikan.

Faktor penghambat dari internal yaitu berasal dari dari guru itu sendiri seperti kurangnya rasa motivasi dalam mengajar sehingga kedisiplian dan kinerja yang dihasilkan pun menjadi kurang, motivasi yang tidak ada menyebabkan guru menjadi kurang bersemangat dalam mengajar sehingga kurang efektif dalam proses mengajar. Dan faktor penghambat dari eksternal yaitu berasal dari orangtua siswa atau lingkungan masyarakat, yang artinya dukungan dari masyarakat akan dapat membantu guru dalam mewujudkan kedisiplinan dan kinerja yang profesional.

Faktor penghambat tersebut oleh kepala madrasah diatasi dengan cara berbicara secara pribadi dan memotivasi guru. Kepala madrasah juga meminta bantuan kepada komite madrasah agar mendukung segala kebijakan yang dibuat agar visi misi dapat tercapai. Apabila faktor pendukung tersebut tidak dapat berjalan dengan baik maka itu yang akan menjadi faktor penghambat. Begitupun dengan pengawasan dari kepala madrasah yang tidak maksimal menyebabkan guru lalai dalam menjalankan tugasnya. 
Selanjutnya, pembahasan dari hasil angket antara lain:

1. Kepala madrasah memberikan kinerja terbaik tanpa menganalisa perubahan zaman, sesuai hasil indikator presentase, yang menjawab selalu sebanyak $11,6 \%$, sering $16,6 \%$, kadang-kadang $65 \%$, tidak pernah 6,8\%. Dengan demikian, kepala madrasah sebagai penentu arah terkadang memberikan kinerja yang baik tanpa menganalisa perubahan zaman dan kurang mempertimbangkan resiko yang akan dihadapi dalam melakukan perubahan. Selaras dengan penelitian Muzakar, bahwa seorang kepala sekolah dituntut kesiapannya untuk selalu berperan dalam setiap perubahan, karena perubahan itu sendiri diperlukan sebagai media dalam rangka pemecahan masalah guna menciptakan kondisi yang lebih baik. Pembaharuan dapat terjadi dalam bentuk yang direncanakan secara matang sebagai gagasan dan rekayasa khusus yang dilakukan para pemimpin. Di sisi lain ada pembaharuan yang terjadi tanpa direncanakan terlebih dahulu, tapi muncul secara tiba- tiba akibat ketidakpuasan dari anggota organisasi terhadap situasi (Muzakar, 2014).

2. Kepala Madrasah menjalin komunikasi yang baik terhadap bawahan, Observasi awal peneliti, peneliti telah melihat dan mengamati dimadrasah tersebut cara menerapkan dari kedisplinan ada dua cara yakni sosialisasi aturan yang berlaku, dari keteladanan dan pembiasaan kepala madrasah. Kemudian, kepala madrasah tersebut sangat menerima aspirasi dengan seluruh warga madrasah dan mengajak musyawarah jika terjadi perselisihan maupun dalam penyelesaian tugas. Selaras dengan hasil penelitian yang dilakukan oleh Maharrani Dwi Cahyaningsih, bahwa pemimpin sudah cukup mampu memberikan pengaruh yang baik dalam menegakkan disiplin sehingga cukup mampu menggerakkan bawahannya untuk melaksanakan peraturan yang ada dan dapat beriteraksi terhadap bawahan/guru. Namun, terkadang guru kurang turut berpartisipasi dalam menegakkan kedisiplinan sehingga peraturan yang ada 
kurang begitu optimal, hal ini disebabkan oleh kepala sekolah yang kurang berperan aktif secara langsung dalam menegakkan peraturan terhadap guru. Serta pembinaan kepala sekolah terhadap guru kurang efektif dalam memotivasi agar mau bekerjasama dan membina hubungan baik agar tujuan organisasi tercapai (Cahyaningsih, 2017).

3. Lebih menyukai pemikiran kovensional daripada paradigma terbaru dan ketidakmampuan mengubah pengetahuan bawahan menjadi strategi, Sesuai dengan hasil indikator mentor nomor 33 presentase yang lebih dominan menjawab kadang-kadang sebesar $38,3 \%$ bahwa kepala madrasah terkadang lebih menyukai pemikiran kovensional daripada paradigma terbaru dan kurang mampu mengubah pengetahuan bawahan menjadi strategi yang mendatangkan pertumbuhan yang berkelanjutan. Dengan demikian, kepala madrasah akan lebih baiknya memperpadukan dan menyeimbangkan pemikiran konvensional dengan paradigma terbaru dengan upaya meningkatkan kualitas madrasah melalui pemberdayaan masyarakat dengan konsep meningkatkan kapasitas para pengelola madrasah cara yang berbeda untuk mampu mendongkrak perubahan lebih baik dengan harapan akan tumbuhnya keunggulan lokal pada setiap madrasah yang mengajarkan dasar-dasar ilmu pengetahuan dan teknologi yang dijiwai nilai-nilai Islam. Selaras dengan jurnal Hamim Tohari bahwa kepala madrasah harus memiliki kemampuan untuk merasakan staf dan memahami sudut pandang bawahan yang mana dapat mengartikulasikan sebuah visi yang benar-benar menginspirasi. Disisi lain, kepala madrasah yang salah membaca stafnya tidak akan bisa menginspirasi mereka yang bisa berdampak terhadap perwujudan visi pimpinan (Tohari, 2017).

4. Guru disiplin dalam hal kehadiran dan berpakaian, Salah satu upaya yang dilakukan oleh kepala madrasah agar seluruh warga madrasah disiplin maka harus terpenuhinya jam kerja selama 7,5 jam perhari dari 07.30 s.d 16.00 
atau 37,5 jam per minggu. Kedisiplinan seorang guru bukan hanya kehadiran, guru harus disiplin menggunakan seragam sesuai dengan jadwal pakaian yang telah ditentukan, guru juga disiplin dalam administrasi jika berhalangan hadir ke madrasah harus membuat surat keterangan, dan guru harus disiplin dalam melaksanakan pembagian tugas yang telah ditentukan. Serta yang paling menarik dari MAN 2 Samarinda, untuk meningkatkan kedisiplinan bahwasanya setiap pagi kepala madrasah telah menunggu didepan gerbang madrasah untuk melihat guru dan siswa yang tepat waktu dan terlambat.

Memperlakukan guru secara berbeda-beda dan mendapatkan pertentangan dalam melakasanakan tugas,Sesuai hasil indikator presentase, yang lebih dominan menjawab kadang-kadang sebesar $61,6 \%$ maka terkadang kepala madrasah memperlakukan guru secara berbeda-beda dan mendapatkan pertentangan dalam melaksanakan tugas. Kepala madrasah sebagai juru bicara harus mampu menentukan kapan harus bersikap demokratis serta otoritas. Oleh karenanya seorang kepala madrasah dalam menjalankan tugas manajerialnya harus mempertimbangkan tingkat karier guru yang dipimpinnya, mengingat guru merupakan ujung tombak perubahan menuju perbaikan kinerja madrasah. Jika kepala madrasah tidak mampu mendongkrak karier guru, maka berakibat lemahnya visi misi yang tidak terlaksana dengan maksimal. Untuk itu kepala madrasah selalu aktif membina para guru untuk selalu berusaha meningkatkan kariernya, dengan cara mengikutkan pelatihan secara bertahap. Hal tersebut membuat guru memahami akan apa yang menjadi kebijakan kepala madrasah sehingga guru senantiasa berusaha menaati dan melaksanakan perintah dari kepala madrasahnya.

\section{KESIMPULAN}

Berdasarkan penelitian yang telah dilakukan maka dapat diambil kesimpulan sebagai berikut:

1. Hasil analisis data menunjukkan bahwa hasil nilai thitung 3,5090> tabel 2,00172, yang berartiHo ditolak dan Ha diterima.Terdapat kolerasi antara variabel $\mathrm{X}$ dengan 
variabel Y, korelasi product diperoleh angka sebesar 0,416 sehingga antara variabel kepemimpinan visioner dan variabel kedisiplinan guru terdapat kolerasi yang cukup kuat.

2. Kepemimpinan visioner terhadap kedisiplinan guru hanya sebesar $17,31 \%$ saja (cukup kuat), faktorfaktor yang menyebabkan hasil tersebut antara lain: memberikan kinerja terbaik tanpa menganalisa perubahan zaman, ketidakmampuan mengubah pengetahuan bawahan menjadi strategi, dan memperlakukan guru secara berbeda-beda sehingga mendapat pertentangan tugas. Sedangkan faktor pendukung dan penghambat dalam membina disiplin guru antara lain: kepribadian seorang guru, kepala madrasah dalam program dan pengawasan terhadap para guru.
Alma, B. Pembelajaran Studi Sosial. Bandung: Alfabeta. 2010

Ambros, L.E., Florarianus, D.A. dan Mikael, N. 2017. Etika dan Tantangan Profesionalisme Guru. Bandung: Alfabeta.

Arikunto, S. 2016. Prosedur Penelitian: Suatu Pendekatan Praktik. Jakarta: Rineka Cipta.

Cahyaningsih, M.D. 2017. Pengaruh Kepemimpinan Kepala Sekolah terhadap Disiplin Guru di SMA Negeri 14 Samarinda. e-Journal Administrasi Negara edisi no. 1, Vol. 5.

Fauzan. 2016. Kepemimpinan Visioner Dalam Manajemen Kesiswaan. dalam Al-Iddarah Jurnal Kependidikan Islam edisi no.1, Vol. 5.

Hafulyon. 2014. Keberagaman Konsep Kepemimpinan dalam Organisasi,. Jurnal al-Fikkrah edisi no.1, Vol. II.

Haryono. 2017. 101 Jurus Jitu Menjadi Guru hebat. Jogjakarta: Ar-Ruzz Media.

Hidayah, N. 2016. Kepemimpinan Visioner Kepala Sekolah dalam Meningkatkan Mutu Pendidikan. Yogyakarta: Ar-Ruzz Media.

Ihsan, F. 1997. Dasar-dasar Kependidikan. Jakarta: PT. Rineka Cipta.

Kodiran. 2017. Kepala Sekolah Sebagai Tugas Tambahan. AlIdarah: Jurnal Kependidikan Islam edisi no. 1, Vol. 7.

Komariah \& Triatna, A.C.. 2010. Visionary Leadership: menuju 
sekolah efektif. Jakarta: Bumi Aksara.

Kompri. 2016. Motivasi Pembelajaran: Perspektif Guru dan Siswa,. Bandung: PT. Remaja Rosdakarya.

Ma'mur, Muttaqin, Jamal. 2010. Tips Menjadi Guru Inspiratif, Kreatif, dan Inovatif. Yogyakarta: Diva Pers.

Muzakar. 2014. Kinerja Kepala Sekolah dalam Meningkatkan Mutu Lulusan pada Madrasah Tsanawiyah Negeri Meureubo. Jurnal Ilmiah Islam Futura edisi no.1, Vol. 14.

Sarmanu. 2017. Dasar Metodologi Penelitian Kuantitatif, Kualitatif \& Statistika. Surabaya: Air langga University Press.

Sonedi. 2013. Kepemimpinan Visioner: Solusi Peningkatan Kualitas Persekolahan. Pedagogik Jurnal pendidikan edisi no.2, Vol. VIII.

Sudja, I N. 2017. The Influences of Education and Training,Leadership, Work Environment, Teacher Certification On Discipline and Teacher's Professionality In High School at Bali Province. Scientific Research Journal (SCIRJ), Issue IX, Vol. V.

Suryana, A.S. 2012. Pngelolaan Pendidikan, Jakarta: Direktorat Jendral Pendidikan Islam Kementrian Agama RI.

Tohari, H. 2017. Gaya Kepemimpinan Berbasis Emotional Intelligence.
Kependidikan edisi no.1, Vol. 5.

Ungguh, J.M. 2014 Metodologi Penelitian Pendidikan dengan Studi Kasus, Yogyakarta: Gava Media, 2014. 